Наносистели, наноматеріали, нанотехнології Nanosistemi, Nanomateriali, Nanotehnologii 2020, т. 18, № 3, cc. 681-695
(C) 2020 ІМФ (Інститут металофізики ім. Г. В. Курдюмова НАН України) Надруковано в Україні. Фотокопіювання дозволено тільки відповідно до ліцензі

PACS numbers: 68.37.Lp, 68.43.Nr, 78.30.-j, 78.40.-q, 78.67.Rb, 82.50.Hp, 82.80.Pv

\title{
The Influence of Sulphur Dopants on Optical, Textural, Structural, and Photocatalytic Properties of Titanium Dioxide
}

\author{
M. V. Shapovalova ${ }^{1}$, T. A. Khalyavka ${ }^{1}$, N. D. Shcherban ${ }^{2}$, O. Y. Khyzhun ${ }^{3}$ \\ V. V. Permyakov ${ }^{4}$, and S. N. Shcherbakov ${ }^{5}$ \\ ${ }^{1}$ Institute for Sorption and Problems of Endoecology, N.A.S. of Ukraine, \\ 13, General Naumov Str., \\ UA-03164 Kyiv, Ukraine \\ ${ }^{2}$ L.V. Pisarzhevsky Institute of Physical Chemistry, N.A.S. of Ukraine, \\ Prospekt Nauky, 31, \\ UA-03028 Kyiv, Ukraine \\ ${ }^{3}$ I. M. Frantsevych Institute for Problems of Materials Science, N.A.S. of Ukraine, \\ 3, Krzhyzhanovs'kyy Str., \\ UA-03142 Kyiv, Ukraine \\ ${ }^{4}$ Institute of Geological Sciences, N.A.S. of Ukraine, \\ 55-b, O. Honchar Str., \\ UA-01054 Kyiv, Ukraine \\ ${ }^{5}$ M. H. Kholodnyy Institute of Botany, N.A.S. of Ukraine, \\ 2, Tereshchenkivs'ka Str., \\ UA-01004 Kyiv, Ukraine
}

Nanoscale composite materials based on titanium dioxide with different content of sulphur are obtained by the sol-gel method. The samples were analysed using SEM-EDS microscopy, transmission electron microscopy (TEM), $\mathrm{x}$-ray diffraction analysis (XRD), x-ray photoelectron spectroscopy (XPS), UV-vis diffuse reflection spectra (DRUV), room temperature FT-IR spectroscopy, and BET method. X-ray powder diffraction reveals the phase of anatase in all composites and appearance of the rutile phase for the samples with sulphur. As established, doping with sulphur leads to a decrease in the crystallite sizes from $\mathbf{1 4 . 6}$ to $\mathbf{9 . 9} \mathrm{nm}$. Analysis of nitrogen sorptiondesorption isotherms for the synthesized samples shows the presence of a hysteresis loop, which is the evidence for mesoporous structure of the powders. The composite samples manifest a bathochromic shift as compared with the absorption band of pure $\mathrm{TiO}_{2}$. As found, the modification of titanium dioxide with sulphur leads to band gap narrowing of the composites. Nanocomposite samples show photocatalytic activity in the destruction of safranin $\mathrm{T}$ under visible irradiation. It can be attributed to the appearance of absorption in the visible region, narrowing of band gap, participation of sulphur in the 
inhibition of electron-hole recombination, prolongation of charges lifetime, increasing efficiency of interfacial charge separation, and change in textural characteristics.

Наномасштабні композиційні матеріяли на основі діоксиду титану з різним вмістом сірки одержували методою золь-ґель. Зразки аналізували за допомогою мікроскопії SEM-EDS, просвітлювальної електронної мікроскопії (TEM), рентґенівської дифракційної аналізи (XRD), рентгенівської фотоелектронної спектроскопії (XPS), ультрафіолетових спектрів дифузного відбивання (DRUV), FT-IR-спектроскопії за кімнатної температури та методи BET. Рентгенівська дифракція порошку виявила фазу анатазу у всіх композитах і появу фази рутилу для зразків із сіркою. Встановлено, що легування сіркою приводить до зменшення розмірів кристалітів з 14,6 до 9,9 нм. Аналіза ізотерм сорбції-десорбції азоту для синтезованих зразків показала наявність петлі гістерези, що є свідченням мезопористої структури порошків. Композитні зразки виявили батохромний зсув порівняно зі смугою поглинання чистого $\mathrm{TiO}_{2}$. Було встановлено, що модифікування діоксиду титану сіркою приводить до звуження зонної щілини композитів. Нанокомпозитні зразки виявляли фотокаталітичну активність при руйнуванні сафраніну Т під видимим опроміненням. Це можна пояснити появою поглинання у видимій області, звуженням зонної щілини, участю сірки у гальмуванні електронно-діркової рекомбінації, подовженням часу життя зарядів, підвищенням ефективности міжфазного зарядового розділення та зміною у текстурних характеристиках.

Key words: titanium dioxide, sulphur, safranin $\mathrm{T}$, photocatalysis, visible light.

Ключові слова: діоксид титану, сірка, сафранін Т, фотокаталіза, видиме світло.

(Received 4 December, 2019)

\section{INTRODUCTION}

It is known that titanium dioxide is widely used as a photocatalyst due to its thermal stability, non-toxicity and low cost. However, it has some disadvantages, such as low quantum yield, high band gap, high electron-hole recombination, and it also absorbs only UV light, so it is photocatalytically active only under UV irradiation.

Over last years, researchers focused on the problem of expanding the absorption range of $\mathrm{TiO}_{2}$ because it seems more practical and favourable to use visible light rather than ultraviolet for the degradation of water pollutants in the presence of photocatalysts. Therefore, an urgent problem in photocatalysis is a search for photocatalytic systems active under visible light irradiation, which gives an opportunity of their widespread practical application. One of the ways to solve this 
problem is the modification of titanium dioxide with different additives [1-6]. Recent studies have largely focused on doping $\mathrm{TiO}_{2}$ with non-metallic elements such as N, S, C, F, etc. [7-11], that leads to an appearance of photocatalytic activity under visible light.

Therefore, the aim of our work was to obtain and characterize composite materials based on titanium dioxide and sulphur with photocatalytic activity under visible irradiation. Photocatalytic activity of the nanocomposites was evaluated through the degradation of cationic dye Safranin T (ST) under visible light irradiation. In addition, we investigated the effect of the sulphur amount in the composites on their physical and photocatalytic properties.

\section{EXPERIMENTAL}

\subsection{Preparation of $\mathrm{TiO}_{2}$ and $\mathrm{S} / \mathrm{TiO}_{2}$ Composites}

Titanium dioxide was obtained by the sol-gel procedure using titanium (IV)-ethylate (Aldrich), citric acid (Alfa Aesar) and glycerol (Alfa Aesar). The mixture of titanium (IV)-ethylate, citric acid and glycerol was calcined at stepwise heating $\left(200^{\circ} \mathrm{C}\right.$ (for $\left.30 \mathrm{~min}\right), 300^{\circ} \mathrm{C}$ (for 30 $\min$ ), $400^{\circ} \mathrm{C}$ (for $30 \mathrm{~min}$ ) and $500^{\circ} \mathrm{C}$ (for $30 \mathrm{~min}$ )) in the presence of air. Before annealing, the mixture was carefully stirred in order to obtain uniform mass. After cooling, $\mathrm{TiO}_{2}$ was triturated until smooth.

To synthesize $\mathrm{TiO}_{2}$ doped with sulphur by the sol-gel procedure the same mixture (titanium (IV)-ethylate, citric acid, glycerol, but with additives of thiourea) was mixed at room temperature, carefully stirred in order to obtain uniform mass and calcined at stepwise heating $\left(200^{\circ} \mathrm{C}\right.$ (for $30 \mathrm{~min}$ ), $300^{\circ} \mathrm{C}$ (for $30 \mathrm{~min}$ ), $400^{\circ} \mathrm{C}$ (for $30 \mathrm{~min}$ ) and $500^{\circ} \mathrm{C}$ (for 30 $\min )$ ) in the presence of air. Then, the powders were cooled and triturated until smooth. The samples were labelled as $1 \mathrm{~S} / \mathrm{TiO}_{2}, 2 \mathrm{~S} / \mathrm{TiO}_{2}$, $3 \mathrm{~S} / \mathrm{TiO}_{2}, 4 \mathrm{~S} / \mathrm{TiO}_{2}$ (with the sulphur amount of $2,3,13,17$ mass. $\%$, respectively).

\subsection{Methods and Instrumentation}

For analysis of the sample composition (elemental analysis) and their morphology a scanning electron microscope (SEM JSM $6490 \mathrm{LV}$, JEOL, Japan) with an integrated system for electron microprobe analysis INCA Energy based on energy-dispersive and wavelengthdispersive spectrometers (EDS + WDS, OXFORD, United Kingdom) with $H K L$ Channel system was used.

Transmission electron microscopy (TEM) JEM-1200 EX (JEOL, Japan) for the prepared materials was applied.

Phase composition of the samples was determined by $\mathrm{x}$-ray diffrac- 
tion analysis (XRD). A computerized Bruker D8 Advance diffractometer was equipped with $\mathrm{Cu} K_{\alpha}(\lambda=0.15406 \mathrm{~nm})$ radiation. All XRD peaks were checked and assigned to known crystalline phases. Average crystallite size was determined using broadening the most intensive reflex following the Debye-Scherrer equation: $D=0.9 \lambda / B \cos \theta$, where 0.9 is a constant, $\lambda$ is a wavelength, $\mathrm{nm}$. Interplanar distance $(d, \mathrm{~nm})$ was calculated using Wulff-Bragg's equation: $n \lambda=2 d \sin \theta$, where $n=1$ is the order of reflection, $\lambda=0.154 \mathrm{~nm}$ is the wavelength, $\theta$ is the scattering angle, degrees. Thereby, $d=n \lambda / 2 \sin \theta$.

The presence of chemical elements and chemical bonds features in the samples were analysed using x-ray photoelectron spectroscopy (XPS) with the UHV-Analysis-System equipment produced by SPECS Surface Nano Analysis Company (Berlin, Germany). The instrument is equipped with a semi-spherical analyser PHOIBOS 150. The XPS spectra, both core-level and valence band, were measured. The acquisition of the XPS spectra was made in an ion-pumped chamber of the system at a residual pressure of (8-9) $10^{-10} \mathrm{mbar}$ and constant pass energy of $40 \mathrm{eV}$. The spectra were excited employing an x-ray $\mathrm{Mg} K_{\alpha}$ source $(E=1253.6 \mathrm{eV})$. The spectrometer energy scale was calibrated using reference metals of pure gold and copper as described in other papers [12]. Since the XPS technique is sensitive to charging surface effects [13], we used the C1s line of adsorbed hydrocarbons as a reference to take into account the charging effect suggesting its binding energy value to be equal to $284.6 \mathrm{eV}$ as recommended to do in the case of complex oxide-bearing materials [14].

The values of the specific surface area $\left(S_{s p}\right)$ of the samples as well as pore size distribution were determined using a Quantachrom Nova Win 2 device. The specific surface area of the samples was determined based on nitrogen adsorption-desorption isotherms using the Brunauer-Emmet-Teller (BET) approach. The pore radius $\left(R_{\max }\right)$ and the pore volume $\left(V_{t o t}\right)$ were calculated from the desorption branches of the isotherms using the Barret-Joiner-Halenda method [15].

Room temperature FT-IR spectra were recorded with a Perkin Elmer Spectrum One spectrometer in the spectral region of 4000-400 $\mathrm{cm}^{-1}$ with spectral resolution of $4 \mathrm{~cm}^{-1}$.

Measurements of UV-vis diffuse reflection spectra (DRUV) of the powders were carried out at room temperature using a Perkin-Elmer Lambda Bio 35 spectrophotometer in the range from 1000 to $200 \mathrm{~nm}$, which allowed converting data of the corresponding spectra using the Kubelka-Munch equation. Recording the diffuse reflection spectra in the coordinates $F(R)=f(\lambda, \mathrm{nm})$, where $F(R)$ is the Kubelka-Munch function, was carried out with a special rate in cuvettes with a layer thickness of the investigated powder material of $3 \mathrm{~mm}$ and a reference sample (MgO). All the materials were ground directly in an agate mortar before recording the DRUV spectra and obtaining constant optical 
characteristics. The absolute and relative errors were $\pm 0.01 \mathrm{eV}$ and $\pm 0.3 \%$, respectively.

\subsection{Photocatalytic Experiments}

Photocatalytic activity of the samples was evaluated by rate constants of destruction $\left(k_{d}\right)$ of cationic dye ST $(C=0.03 \mathrm{~g} / \mathrm{l})$ under UV irradiation. Before irradiation, the catalyst suspension $(2 \mathrm{~g} / \mathrm{l})$ in an aqueous dye solution was kept in dark up to achieve adsorption equilibrium. The time of the sorption equilibrium establishment in the system powder-ST does not exceed $2 \mathrm{~h}$ for all samples.

Irradiation of aqueous solutions $(\mathrm{pH}-6.5)$ of dye was performed at room temperature in a reactor in the presence of air oxygen. The light source was a high-intensity Na discharge lamp GE Lucalox (Hungary) with power of $70 \mathrm{~W}$, with emission in the visible range with maxima at 568,590 and $600 \mathrm{~nm}$.

Concentrations of the substrate were measured spectrophometrically using a Shimadzu UV-2450 spectrophotometer at $\lambda=520 \mathrm{~nm}$ for ST. Photocatalytic rate constants for the model compound were calculated using the first order kinetic equation.

\section{RESULTS AND DISCUSSION}

The obtained samples consist of fragmented agglomerates (Fig. 1, $a$ ). Investigation of the powders using energy-dispersive spectroscopy based on energy-dispersive technique proves that these materials include the elements $\mathrm{Ti}, \mathrm{O}$ and $\mathrm{S}$, no unexpected elements were detected
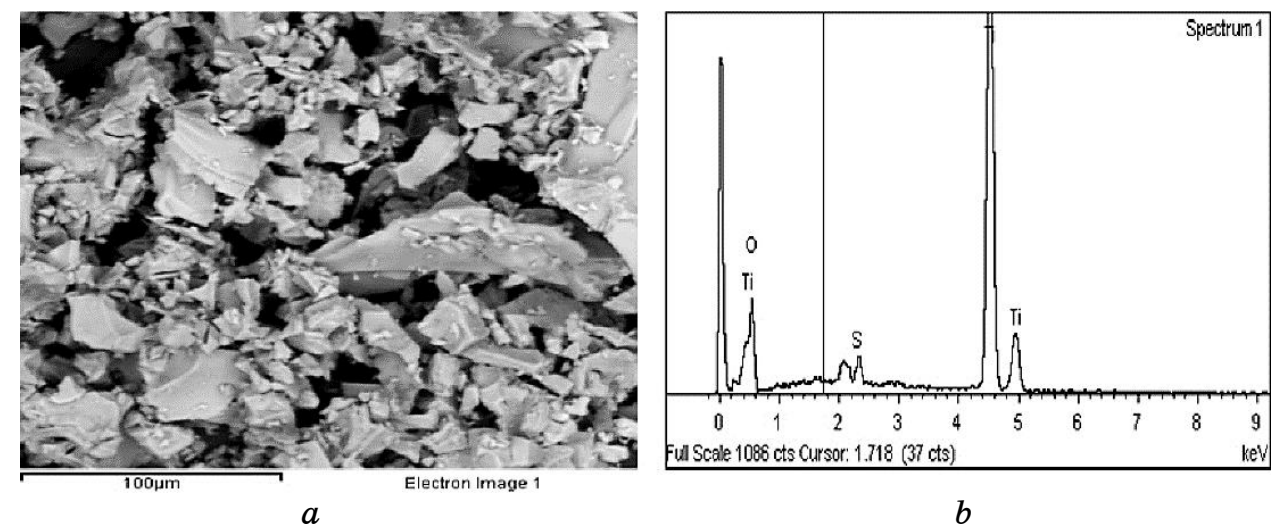

Fig. 1. SEM-image $(a)$ and energy-dispersive spectrometry (EDS) spectrum (b) of the $3 \mathrm{~S} / \mathrm{TiO}_{2}$ sample. 
(Fig. 1,b).

Crystalline structure of the photocatalysts was identified using XRD. XRD pattern of pure titanium dioxide shows the reflexes of tetragonal modification of $\mathrm{TiO}_{2}$ at $2 \theta=25.38,37.93,48.17,54.16,55.09$ and 62.88 (Fig. 2, a), which correspond to the (101), (004), (200), (105), (211), (213) planes, respectively and belongs to the anatase phase. Some authors $[16,17]$ reported that doping $\mathrm{TiO}_{2}$ with sulphur inhibits the anatase-rutile phase transformation, but in our case introduction of sulphur into $\mathrm{TiO}_{2}$ leads to the appearance of the reflex at $2 \theta=27.4$ (110) corresponding to rutile $\mathrm{TiO}_{2}$ (Fig. 2, b).
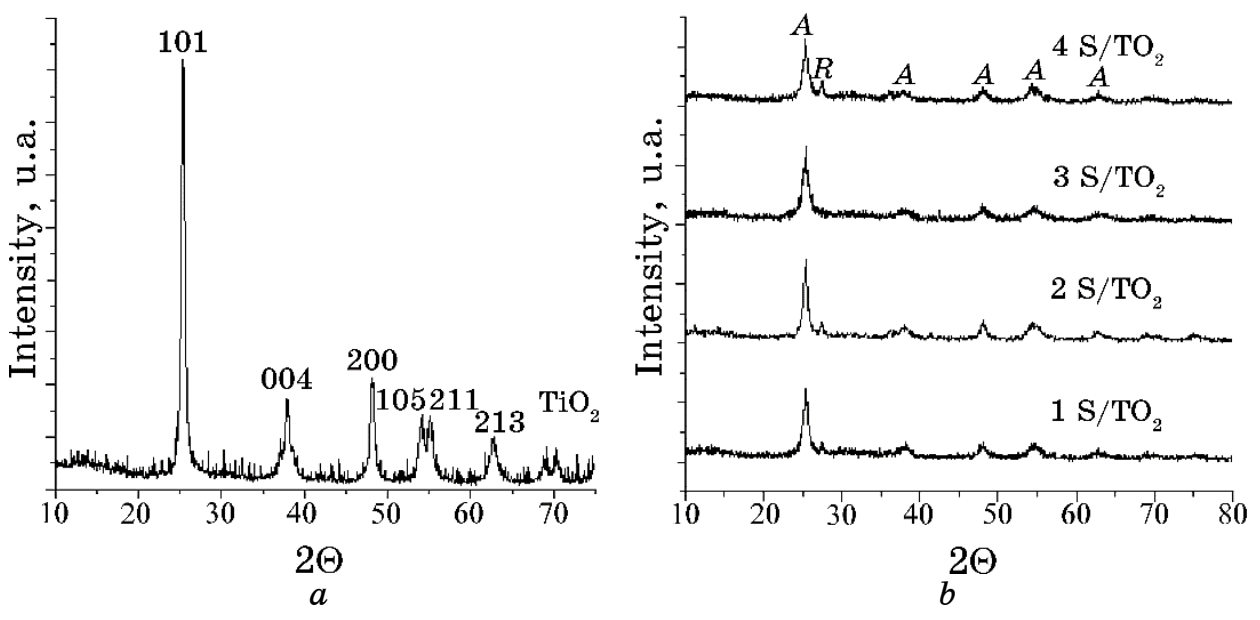

Fig. 2. XRD patterns of $\mathrm{TiO}_{2}(a)$ and $\mathrm{S} / \mathrm{TiO}_{2}$ samples $(b)(A$-anatase, $R$-rutile).

TABLE 1. Phase composition and structural characteristics of the samples.

\begin{tabular}{|c|c|c|c|}
\hline \multirow[t]{2}{*}{ Sample } & \multirow{2}{*}{$\underset{\AA}{\text { Lattice parameters, }}$} & $\begin{array}{c}\text { Interplanar spacing, } \\
d, \mathrm{~nm}\end{array}$ & $\begin{array}{c}\text { Crystallite size, } \\
D_{h k l}, \mathrm{~nm} \\
\end{array}$ \\
\hline & & \multicolumn{2}{|c|}{ (Miller index, $h k l), 101-$ anatase } \\
\hline $\mathrm{TiO}_{2}$ & $\begin{array}{l}a=3.70939 \\
c=9.31095\end{array}$ & $\begin{array}{l}0.350 \\
(101)\end{array}$ & $\begin{array}{c}14.6 \\
(101)\end{array}$ \\
\hline $1 \mathrm{~S} / \mathrm{TiO}_{2}$ & $\begin{array}{l}a=3.76161 \\
c=9.48529\end{array}$ & $\begin{array}{l}0.352 \\
(101)\end{array}$ & $\begin{array}{c}9.9 \\
(101)\end{array}$ \\
\hline $2 \mathrm{~S} / \mathrm{TiO}_{2}$ & $\begin{array}{l}a=3.75125 \\
c=9.49874\end{array}$ & $\begin{array}{l}0.351 \\
(101)\end{array}$ & $\begin{array}{l}10.9 \\
(101)\end{array}$ \\
\hline $3 \mathrm{~S} / \mathrm{TiO}_{2}$ & $\begin{array}{l}a=3.76682 \\
c=9.43419\end{array}$ & $\begin{array}{l}0.351 \\
(101)\end{array}$ & $\begin{array}{l}10.5 \\
(101)\end{array}$ \\
\hline $4 \mathrm{~S} / \mathrm{TiO}_{2}$ & $\begin{array}{l}a=3.75136 \\
c=9.47095\end{array}$ & $\begin{array}{l}0.352 \\
(101)\end{array}$ & $\begin{array}{c}9.9 \\
(101)\end{array}$ \\
\hline
\end{tabular}


In addition, small shift towards higher diffraction angles for $\mathrm{S} / \mathrm{TiO}_{2}$ samples is observed due to the incorporation of dopant ion into the $\mathrm{TiO}_{2}$ matrix [17]. Besides, an increase in the lattice parameters and interplanar spacing for $\mathrm{S} / \mathrm{TiO}_{2}$ compare to $\mathrm{TiO}_{2}$ was observed (Table 1).

Therefore, the lattice parameters for pure $\mathrm{TiO}_{2}$ are about $a=3.70939$ $\AA, c=9.31095 \AA$, while for $\mathrm{S} / \mathrm{TiO}_{2 \sim} a=3.76161 \AA, c=9.47095 \AA$, the interplanar spacing for pure $\mathrm{TiO}_{2}$ is $0.350 \AA$ and for $\mathrm{S} / \mathrm{TiO}_{2}$ is $0.352 \AA$ (Table 1). Such an increase in the lattice parameters for $\mathrm{S} / \mathrm{TiO}_{2}$ compare to $\mathrm{TiO}_{2}$ confirms the incorporation of sulphur ions into the $\mathrm{TiO}_{2}$ lattice.

The crystallites size of the samples calculated through DebyeScherrer equation in the pure $\mathrm{TiO}_{2}$ is equal to $14.6 \mathrm{~nm}$. Doping with sulphur leads to a decrease of the crystallite sizes to $9.9 \mathrm{~nm}$ (Table 1), which is confirmed by the TEM images (Fig. 3). Therefore, the incorporation of $\mathrm{S}$ atoms into the lattice inhibits the crystal growth of the $\mathrm{TiO}_{2}$ particles.

Analysis of nitrogen sorption-desorption isotherms obtained at $20^{\circ} \mathrm{C}$ for the synthesized samples (Fig. 4, $a$ ) shows the presence of a hysteresis loop [18]. It was established that for all samples, nitrogen sorption isotherms belong to type IV in accordance with International Union of Pure and Applied Chemistry (IUPAC) classification with $\mathrm{H}_{2}$ type of hysteresis loop [19].

The pore size distribution for the samples is shown in Fig. 4, $b$. Predominance of the pores' radius ranging from 1.9 to $2.3 \mathrm{~nm}$ is characteristic of the composites.

Pore volume twice increased for the $\mathrm{S} / \mathrm{TiO}_{2}$ samples (Table 2). The specific surface area of the composites increases from 28.4 (pure titanium dioxide) to $94.5 \mathrm{mI} / \mathrm{g}\left(4 \mathrm{~S} / \mathrm{TiO}_{2}\right)$ (Table 2$)$. Such a porous structure can provide a larger number of active sites for dye adsorption and latter photodestruction.

X-ray photoelectron spectroscopy (XPS) was used to verify the elemental content and charge state of the atoms composing the $\mathrm{TiO}_{2}$ and $\mathrm{S} / \mathrm{TiO}_{2}$ samples. The survey XPS spectra are shown in Fig. 5.

The features of the XPS spectra in all samples can be attributed to the core-level electronic levels of titanium and oxygen atoms, and the presence of sulphur is detected for $\mathrm{S} / \mathrm{TiO}_{2}$ composites. Modification of titanium dioxide with sulphur does not lead to the appearance of some fine-structure features or to change in the energy position of the XPS spectra of core-level electrons (Table 3).

It was noted that a sulphur-containing material was characterized by a binding energy value of around $170 \mathrm{eV}$ [20]. In our samples, the peak at $168.9 \mathrm{eV}$ is observed and proves the presence of sulphur (Fig. 5, $6, a)$. Binding energy of $\mathrm{S} 2 p$-electrons in $\mathrm{S} / \mathrm{TiO}_{2}$ composites (Table 3, Fig. 6, a) corresponds to sulphur atoms in the compounds of $\mathrm{Na}_{2} \mathrm{SO}_{4}$ and $\mathrm{Fe}_{2}\left(\mathrm{SO}_{4}\right)_{3}$ (Table 3, Fig. 6, $\left.a\right)$ [21, 22].

The data show the absence of additional admixtures except of ad- 

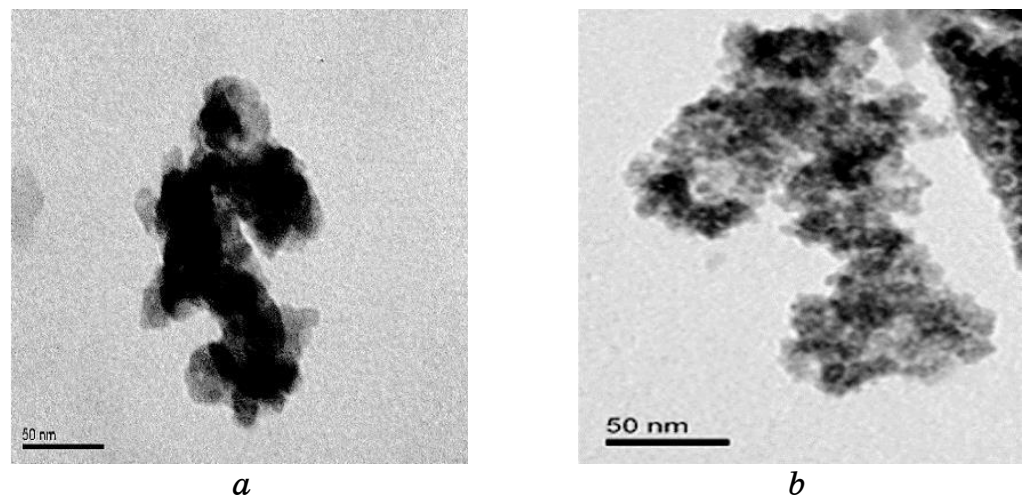

Fig. 3. TEM-images: $a-\mathrm{TiO}_{2} ; b-3 \mathrm{~S} / \mathrm{TiO}_{2}$ sample.
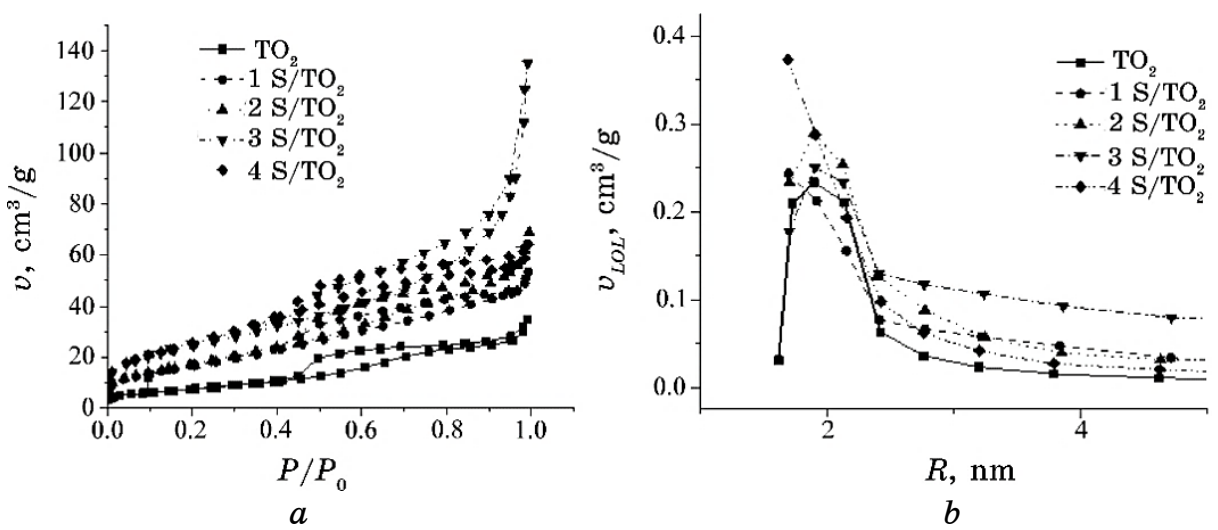

Fig. 4. Isotherms of nitrogen sorption-desorption obtained at $20^{\circ} \mathrm{C}$ for the investigated samples $(a)$ and pore size distribution for the samples $(b)$.

sorbed hydrocarbons (Fig. 6, $d$ ). The result proves that binding energy values of titanium in $\mathrm{TiO}_{2}$ and $\mathrm{S} / \mathrm{TiO}_{2}$ correspond to the charge state +4 $\left(\mathrm{TiO}_{2}\right)[21,22]$.

Energy positions of the XPS spectra of core-level Ti2 $p_{3 / 2^{-}}$and $\mathrm{O} 1 s$ electrons (Table 3, Fig. 6, $b, c$ ) in the investigated samples are similar to previous researches [23] and was characterized by the values of binding energies of $\mathrm{Ti} 2 p_{3 / 2}$ and $\mathrm{O} 1 s$-electrons in $\mathrm{TiO}_{2}(458.6-459.1 \mathrm{eV}$ for $\mathrm{Ti} 2 p_{3 / 2}$-electrons and about $530.4 \mathrm{eV}$ for $\mathrm{O} 1 s$-electrons) [23].

It can be seen from Fig. 5, $d$ that C1s spectra at 289.8 to $273.9 \mathrm{eV}$ can be observed. The peak (about $285 \mathrm{eV}$ ) is thought to signal the presence of adventitious elemental carbon. This peak is lower for the $\mathrm{S} / \mathrm{TiO}_{2}$ sample, which is related to decreasing the carbon amount in the sample and may mean its relocation by sulphur. The hydrocarbons were 
TABLE 2. Textural characteristics of the samples.

\begin{tabular}{c|c|c|c}
\hline Sample & $S_{s p}, \mathrm{mI} / \mathrm{g}$ & $V_{\text {tot }}, \mathrm{cmi} / \mathrm{g}$ & $R_{\max }, \mathrm{nm}$ \\
\hline $\mathrm{TiO}_{2}$ & 28.4 & 0.05 & 1.9 \\
$1 \mathrm{~S} / \mathrm{TiO}_{2}$ & 61.7 & 0.08 & 1.7 \\
$2 \mathrm{~S} / \mathrm{TiO}_{2}$ & 62.2 & 0.11 & 1.9 \\
$3 \mathrm{~S} / \mathrm{TiO}_{2}$ & 87.9 & 0.21 & 1.9 \\
$4 \mathrm{~S} / \mathrm{TiO}_{2}$ & 94.5 & 0.09 & 1.7 \\
\hline
\end{tabular}

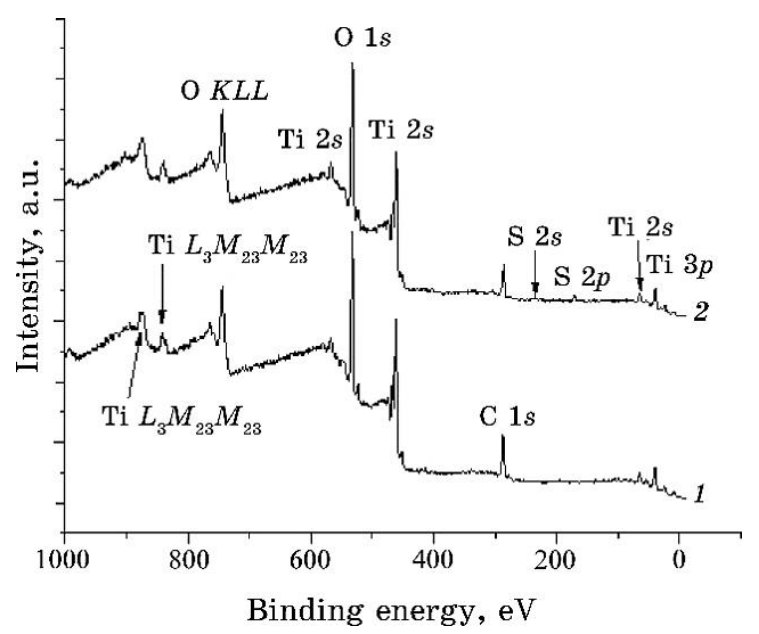

Fig. 5. XPS spectra of the studied samples: $\mathrm{TiO}_{2}(1)$ and $4 \mathrm{~S} / \mathrm{TiO}_{2}(2)$.

the only detected admixtures (Fig. 5 and $6, d$ ).

The $\mathrm{O} 1 s$ binding energy of $\mathrm{S} / \mathrm{TiO}_{2}$ increases by $0.4 \pm 0.1 \mathrm{eV}$ compare to $\mathrm{TiO}_{2}$ (Table 3, Fig. 6, b). It means that addition/inclusion of sulphur atoms into $\mathrm{TiO}_{2}$ decreases negative charge state of oxygen. The above statement is supported also by increasing the binding energy value of the O2s subband (Fig. 7) (Table 2). Estimation of the elemental content gives the following data: $\mathrm{Ti}: \mathrm{O}: \mathrm{C}=21.7: 46.8: 31.5$ for $\mathrm{TiO}_{2}$ and Ti:O:C:S=23.6:48.5:25.3:2.6 for $\mathrm{S} / \mathrm{TiO}_{2}$. Therefore, substantial decrease of the $\mathrm{C}$ content in the $\mathrm{S} / \mathrm{TiO}_{2}$ sample compare to $\mathrm{TiO}_{2}$ is observed. The half-width of the main XPS valence band spectrum does not change in the above sequence of the compounds (Fig. 7).

The functional groups of the synthesized samples were characterized by FTIR transmittance spectroscopy and the corresponding spectra are shown in Fig. 8.

The bands near $500-900 \mathrm{~cm}^{-1}$ corresponding to the Ti-O-Ti stretching vibration, and near $910-1050 \mathrm{~cm}^{-1}$ to $\mathrm{Ti}-\mathrm{O}[24,25]$ are present in all samples (Fig. 8). 
TABLE 3. Binding energies of core-level electrons $( \pm 0.1 \mathrm{eV})$ of $\mathrm{TiO}_{2}$ and $\mathrm{S} / \mathrm{TiO}_{2}$

\begin{tabular}{c|c|c}
\hline Core-level & $\mathrm{TiO}_{2}$ & $\mathrm{~S} / \mathrm{TiO}_{2}$ \\
\hline $\mathrm{Ti} 2 p_{1 / 2}$ & 464.5 & 464.6 \\
$\mathrm{Ti} 2 p_{3 / 2}$ & 458.8 & 458.8 \\
$\mathrm{O} 1 s$ & 530.1 & 530.5 \\
$\mathrm{~S} 2 p$ & - & 168.9 \\
$\mathrm{Ti} 3 p$ & 37.4 & 37.4 \\
$\mathrm{O} 2 s$ & 22.1 & 22.4 \\
\hline
\end{tabular}
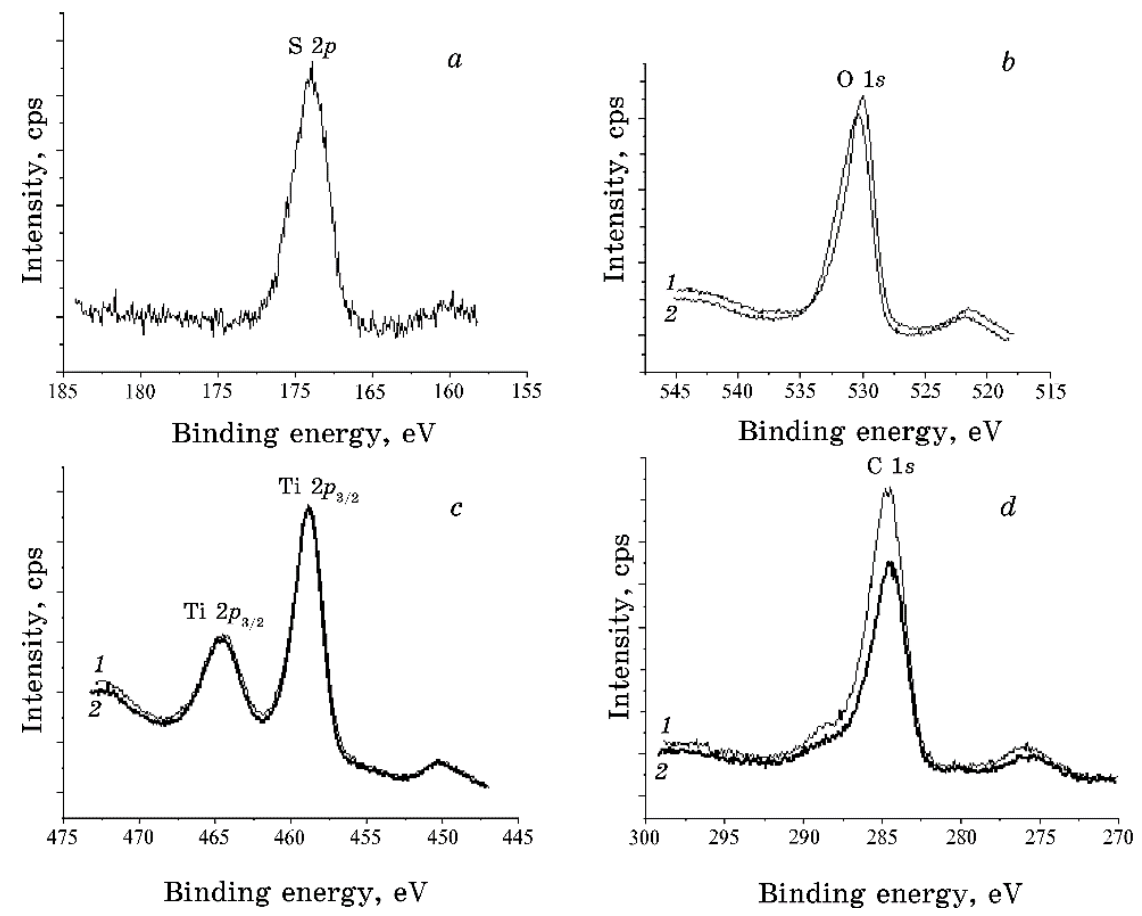

Fig. 6. XPS spectra of core-level $\mathrm{S} 2 p(a), \mathrm{O} 1 s(b)$, and Ti2p $(c)$ electrons and valence electrons $(d)$ of $\mathrm{TiO}_{2}(1)$ and $\mathrm{S} / \mathrm{TiO}_{2}(2)$.

The presence of an additional band in the range of $1100-1050 \mathrm{~cm}^{-1}$ is related to $\mathrm{S}=\mathrm{O}$ vibrations, while at $1200-1100 \mathrm{~cm}^{-1}$ to $\mathrm{O}_{2}$ vibrations [26]. The presence of the band at $1133 \mathrm{~cm}^{-1}$ corresponds to the $\mathrm{S}-\mathrm{O}$ vibration and more specifically to a characteristic frequency of bidentate $\mathrm{SO}_{4}{ }^{2-}$ functional group coordinated to $\mathrm{Ti}^{4+}$ ion [27]. The vibrations of $\mathrm{Ti}-\mathrm{O}-\mathrm{S}$ bond give a peak at $1040 \mathrm{~cm}^{-1}$ that confirms the incorporation of sulphur into $\mathrm{TiO}_{2}$ lattice [28]. The absorption band at $1630 \mathrm{~cm}^{-1}$ refers to deformational vibrations in adsorbed water [29], at $2340 \mathrm{~cm}^{-1}$ to the carbon 


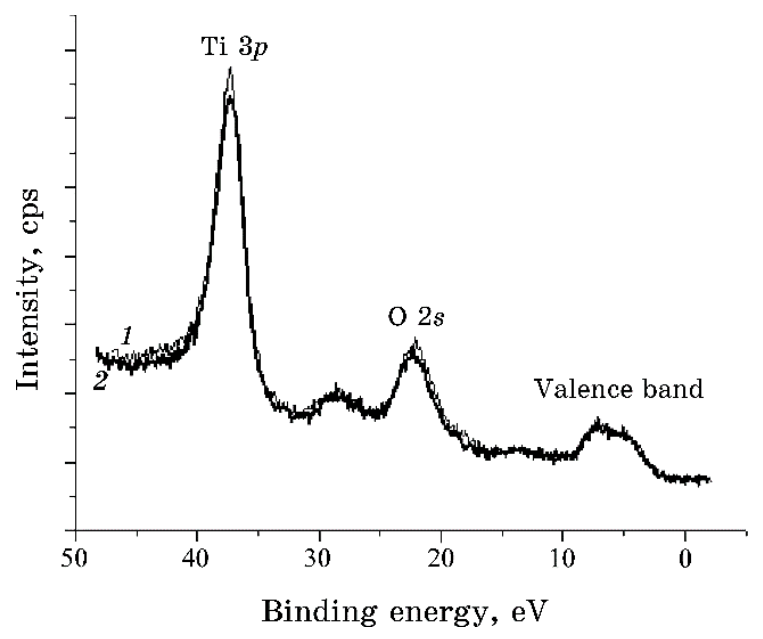

Fig. 7. XPS valence band spectra (including some higher core-level lines) of the $\mathrm{TiO}_{2}(1)$ and $\mathrm{S} / \mathrm{TiO}_{2}$ samples (2).

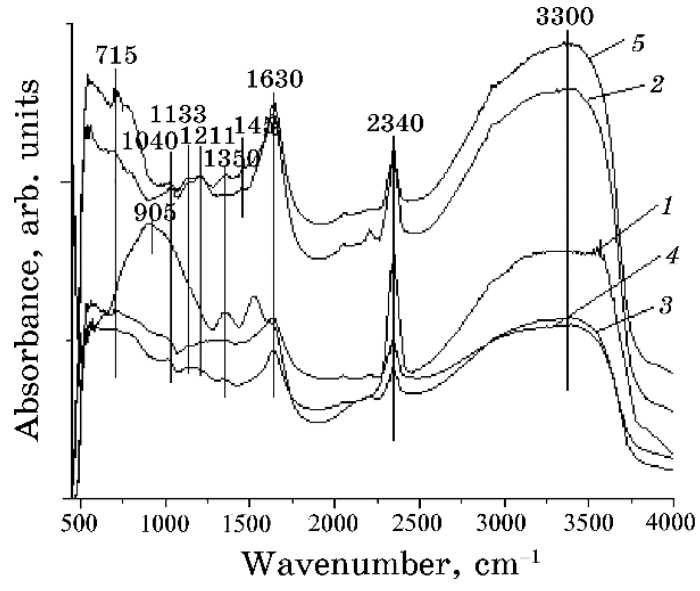

Fig. 8: FT-IR spectra of the nanocomposites: $1-\mathrm{TiO}_{2} ; 2-1 \mathrm{~S} / \mathrm{TiO}_{2} ; 3-$ $2 \mathrm{~S} / \mathrm{TiO}_{2} ; 4-3 \mathrm{~S} / \mathrm{TiO}_{2} ; 5-4 \mathrm{STiO}_{2}$.

dioxide physically sorbed on the surface [30, 31]. In the region of about $3200-3400 \mathrm{~cm}^{-1}$ intensive broad absorption bands of $\mathrm{v}(\mathrm{OH})$ valence vibrations and adsorbed water molecules coordinated on the $\mathrm{TiO}_{2}$ surface are observed for all the samples. These $\mathrm{OH}$ groups after irradiation with light form $\mathrm{OH}$ radicals, which are directly involved in the process of photodegradation of organic compounds.

The DRUV spectra of the investigated samples are shown in Fig. 9. Doping of titanium dioxide by sulphur leads to the appearance of bath- 


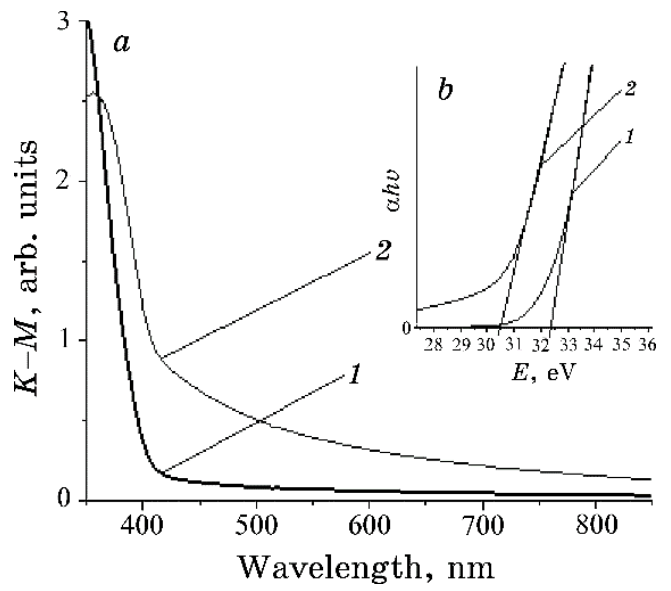

Fig. 9. $a-\mathrm{DRUV}$ spectra of the samples: $1-\mathrm{TiO}_{2} ; 2-2 \mathrm{~S} / \mathrm{TiO}_{2} \cdot b-$ Square of extinction coefficient as a dependence on incident irradiation energy for the powders: $1-\mathrm{TiO}_{2} ; 2-2 \mathrm{~S} / \mathrm{TiO}_{2}$.

TABLE 4. Photocatalytic activity of the investigated samples in the destruction of Safranin $T$ under visible light irradiation.

\begin{tabular}{cc}
\hline Sample & $k_{d} \cdot 10^{-4}, \mathrm{~s}^{-1}$ \\
\hline $\mathrm{TiO}_{2}$ & - \\
$1 \mathrm{~S} / \mathrm{TiO}_{2}$ & 0.27 \\
$2 \mathrm{~S} / \mathrm{TiO}_{2}$ & 0.61 \\
$3 \mathrm{~S} / \mathrm{TiO}_{2}$ & 0.96 \\
$4 \mathrm{~S} / \mathrm{TiO}_{2}$ & 1.76 \\
\hline
\end{tabular}

ochromic shift, the absorption edge from $\mathrm{TiO}_{2}$ to composites is placed to a longer wavelength from 400 to $420 \mathrm{~nm}$ (Fig. 9, $a$ ).

In addition, modification of titanium dioxide with sulphur leads to reduce the energy required for photoactivation from $3.23 \pm 0.01\left(\mathrm{TiO}_{2}\right)$ to $3.04 \pm 0.01\left(4 \mathrm{~S} / \mathrm{TiO}_{2}\right) \mathrm{eV}$.

The ST photodegradation was tested as a model reaction to evaluate photocatalytic activity of the $\mathrm{S} / \mathrm{TiO}_{2}$ powders. Prior to irradiation, photocatalyst-dye systems were kept in the dark to achieve sorption equilibrium. The adsorption-desorption equilibrium was achieved within $120 \mathrm{~min}$. The sorption value of the dye on $\mathrm{S} / \mathrm{TiO}_{2}$ was $25,28,30$ and $35 \%$.

During the irradiation of Safranin $\mathrm{T}$ with visible light (in the absence and in the presence of titanium dioxide), the destruction of the dye did not occur (Table 4).

When the dye water solutions were irradiated with visible light in 
the presence of the composites, a decrease of ST concentrations was observed. The photocatalytic activity of the composites upon irradiation by visible light can be attributed to the appearance of absorption in the visible region.

The rate of the process under visible irradiation was dependent on the catalyst composition and structure (Table 4). The $4 \mathrm{~S} / \mathrm{TiO}_{2}$ sample was the most active. In addition, the values of photocatalytic activity constants correlate $(R=0.9)$ with adsorption parameters for the corresponding samples, indicating that the substrate molecules sorbed on the catalyst surface were first subjected to the photocatalytic transformation. The enhanced photocatalytic performance of the nanocomposites is attributable to the appearance of absorption in the visible light region, change in the band gap, participation of sulphur in the inhibition of electron-hole recombination, prolongation of charges lifetime, increasing efficiency of interfacial charge separation and change in the textural characteristics.

\section{CONCLUSIONS}

Mesoporous nanocomposite materials based on titanium dioxide and sulphur (various content) were obtained by sol-gel method. It was found that these materials have a uniform distribution of $\mathrm{Ti}, \mathrm{S}$ and $\mathrm{O}$. It was established that the nanocomposites crystallize in anatase-type structure, but doping with sulphur leads to the formation of the rutile structure. The additives of sulphur to $\mathrm{TiO}_{2}$ also lead to the reduction of particle size from 14.6 to $9.9 \mathrm{~nm}$ and increase of pore volume twice and specific surface area from 28.4 to $94.5 \mathrm{mI} / \mathrm{g}$.

XRD, FTIR and XPS studies confirm the incorporation of sulphur into lattice as cations and modification as sulphate groups on the surface of $\mathrm{TiO}_{2}$.

The composite samples showed a bathochromic shift to the longwave range and their band gap is decreased compared to the band gap of pure $\mathrm{TiO}_{2}$. It was found that the nanocomposites were photocatalytically active in the destruction of cationic dye under visible light irradiation in contrast with pure titanium dioxide, which acts as a photocatalyst only under UV irradiation. It can be attributed to the appearance of absorption in the visible region, narrowing of the band gap, participation of sulphur in the inhibition of electron-hole recombination, prolongation of charges lifetime, increasing of efficiency of interfacial charge separation and change in textural characteristics.

\section{REFERENCES}

1. M. Ismael, New J.Chem., 43: 9596 (2019); https://doi.org/10.1039/c9nj02226k.

2. G. Di Liberto, S. Tosoni, and G. Pacchioni, Phys. Chem. Chem. Phys., 21: 
21497 (2019); https://doi.org/10.1039/c9cp03930a.

3. O. Linnik, E. Manuilov, S. Snegir, N. Smirnova, and A. Eremenko, J. Adv. Oxid. Technol., 12: 265 (2009); https://doi.org/10.1515/jaots-2009-0218.

4. V. Kumaravel, S. Rhatigan, S. Mathew, J. Bartlett, M. Nolan, S.J. Hinder, P. K. Sharma, A. Singh, J. A. Byrne, J. Harrison, and S. C. Pillai, J. Phys. Chem. C, 123: 21083 (2019); https://doi.org/10.1021/acs.jpcc.9b06811.

5. N. P. Smirnova, E. V. Manuilov, O. M. Korduban, Y. I. Gnatyuk, V. O. Kandyba, A. M. Eremenko, P. P. Gorbyk, and A. P. Shpak, Nanomater. Supramol. Struct. Physics, Chem.Appl. (2009); https://doi.org/10.1007/978-90-481-2309-4.

6. T. A. Khalyavka, N. D. Shcherban, V. V. Shymanovska, E. V. Manuilov, V. V. Permyakov, and S. N. Shcherbakov, Res. Chem. Intermed., 45: 4029 (2019); https://doi.org/10.1007/s11164-019-03888-z.

7. M. Barberio, A. Imbrogno, D. Remo Grosso, A. Bonanno, and Fang Xu, J. Chem. Chem. Eng., 9: 245 (2015); https://doi.org/10.17265/19347375/2015.04.002.

8. N. Chorna, N. Smirnova, V. Vorobets, G. Kolbasov, and O. Linnik, Appl. Surf. Sci., 473: 343-351 (2019);

https://doi.org/10.1016/j.apsusc.2018.12.154.

9. S. Wang, L. Zhao, L. Bai, J. Yan, Q. Jiang, and J. Lian, J. Mater. Chem. A, 2: 7439 (2014); https://doi.org/10.1039/c4ta00354c.

10. M. V. Bondarenko, T. A. Khalyavka, A. K. Melnyk, S. V. Camyshan, and Y. V. Panasuk, J. Nano- Electron. Phys., 10: 06039-1 (2018); https://doi.org/10.21272/jnep.10(6);06039.

11. M. V. Bondarenko, T. A. Khalyavka, N. D. Shcherban, and N. N. Tsyba, Nanosistemi, Nanomateriali, Nanotehnologii, 15: 99 (2017); https://doi.org/10.15407/nnn.15.01.0099.

12. S. Rajagopal, D. Nataraj, O.Y. Khyzhun, Y. Djaoued, J. Robichaud, K. Senthil, and D. Mangalaraj, Cryst. Eng. Comm., 13: 2358 (2011); https://doi.org/10.1039/c0ce00303d.

13. S. Hüfner, Photoelectron Spectroscopy: Principles and Applications (BerlinHeidelberg: Springer-Verlag: 2003).

14. V. V. Atuchin, O. Y. Khyzhun, O. D. Chimitova, M. S. Molokeev, T. A. Gavrilova, B. G. Bazarov, and J. G. Bazarova, J. Phys. Chem. Solids, 77: 101 (2015); https://doi.org/10.1016/j.jpcs.2014.09.012.

15. E. P. Barrett, L. G. Joyner, and P. P. Halenda, J. Am. Chem. Soc., 73: 373 (1951); https://doi.org/10.1021/ja01145a126.

16. E. M. Rockafellow, L. K. Stewart, and W. S. Jenks, Appl. Catal. B Environ., 91: 554 (2009); https://doi.org/10.1016/j.apcatb.2009.06.027.

17. L. Gomathi Devi and R. Kavitha, Mater. Chem. Phys., 143: 1300 (2014); http://dx.doi.org/10.1016/j.matchemphys.2013.11.038.

18. S. Lowell and J. Shields, Powder Surface Area and Porosity (London: Chapman \& Hall: 1991).

19. K. Sing, D. Everett, R. Haul, L. Moscou, R. Pierotti, J. Rouquerol, and T. Siemieniewska, Pur Appl. Chem., 57: 420 (1995).

20. G. Colyn, M. Maicu, M. C. Hidalgo, and J. A. Navío, Appl. Catal. B Environ., 67: 41 (2006); https://doi.org/10.1016/j.apcatb.2006.03.019.

21. J. C. Riviere and M. Sverre, Handbook of Surface and Interface Analysis Methods for Problem-Solving (Boca Raton-London-New York: CRC Press: 2009).

22. D. Briggs and P. M. Seach, Practical Surface Analysis: Auger and X-Ray 
Photoelectron Spectroscopy (Chichester: John Willey \& Sons Ltd.: 1990).

23. C. D. Wagner, W. M. Riggs, L. E. Davis, J. F. Moulder, and G. E. Muilenberg, Handbook of X-Ray Photoelectron Spectroscopy (Eden Prairie, Minnesota, USA: Perkin-Elmer Corp., Physical Electronics Division: 1979).

24. A. Ansyn-Casaos, I. Tacchini, A. Unzue, and M. T. Martínez, Appl. Surf. Sci., 270: 675 (2013); https://doi.org/10.1016/j.apsusc.2013.01.120.

25. Z. W. Qu and G. J. Kroes, Phys. Chem. B, 110: 8998 (2006); https://doi.org/10.1021/jp056607p.

26. A. Davydov, IK-Spektroskopiya $v$ Khimii Poverkhnosti Okislov (Novosibirsk: Nauka: 1984) (in Russian).

27. D. I. Sayago, P. Serrano, O. Bohme, A. Goldoni, G. Paolucci, E. Roman, and J. A. Martin-Gago, Surf. Sci., 482: 9 (2001); doi: 10.1016/S00396028(00)00998-5.

28. S. T. Hussain, K. Khan, and R. Hussain, J. Nat. Gas Chem., 18: 383 (2009); https://doi.org/10.1016/S1003-9953(08)60133-4.

29. Z. Ding, G. Q. Lu, and P. F. Greenfield, J. Phys. Chem. B, 104: 4799 (2000); https://doi.org/10.1021/jp993819b.

30. E. T. Bender, P. Katta, A. Lotus, S. J. Park, G. G. Chase, and R. D. Ramsier, Chem. Phys. Lett., 423: 302 (2006); https://doi.org/10.1016/j.cplett.2006.03.092.

31. L. E. Davies, N. A. Bonini, S. Locatelli, and E. E. Gonzo, Lat. Amer. Appl. Res., 35: 23 (2005). 